\title{
Detection the Prevalence of Hepatitis C Virus among Iraqi People
}

\author{
Hasan Abd Ali Khudhair ${ }^{1 *}$ \\ Ali A. H. Albakaa ${ }^{2}$ \\ Khwam R. Hussein ${ }^{3}$ \\ ${ }^{1-3}$ Southern Technical University, Al-Nasiriyah Technical Institute, Iraq. \\ *Email ID: hasanabdali89@stu.edu.iq
}

\begin{abstract}
Hepatitis $\mathrm{C}$ virus (HCV) infection is a major public health problem worldwide and remains a vital cause of chronic hepatitis. This study was aimed to detect the prevalence of HCV infection among Iraqi people. Four subjects of hemodialysis (HD) patients, thalassemia patients, blood donors and medical staff were enrolled in this study and evaluated for their serum anti-HCV-immunoglobulin $\mathrm{G}$ (IgG)-antibodies (Abs). The total frequency $\%$ of IgG anti-HCV Abs positivity was 3.2\%, in which the highest frequency \% was recorded among thalassemia patients followed by HD patients and then medical staff subjects, whereas the lowest frequency rate was reported within blood donors group. The frequencies of IgG anti-HCV Abs positivity were significantly elevated in males compared to females. For age groups, the results revealed higher infection rate of HCV among age group of 1-20 year followed by the age group of 21-40 year and then age group of 41-60 year, whereas the lowest rate of infection was recorded in age group $>60$ year. In conclusions, the prevalence rate of $\mathrm{HCV}$ infection among Iraqi people is similar to those in most of Asian and non-Asian studied populations and the infection rate was higher in males and inversely correlated with age of the patients. Blood transfusion, renal dialysis and health care workers (HCWs) were major sources of $\mathrm{HCV}$ infection. Thus, we recommend continuing surveillance of blood donors, HCWs and patients, in addition to $\mathrm{HCV}$ markers screening by molecular technique for the diagnosis of $\mathrm{HCV}$ during the window period in order to decrease the prevalence of HCV infection.
\end{abstract}

Key Words: Hepatitis C virus, prevalence and control.

\section{INTRODUCTION}

Hepatitis $C$ virus is a small enveloped ribonucleic acid (RNA) virus belonging to the family Flaviviridae and genus hepacivirus. Hepatitis $\mathrm{C}$ virus genomic RNA was single-stranded with positive polarity, which was packaged by core protein and enveloped by a lipid bilayer containing two viral glycoproteins (E1 and E2) to form the virion. Despite the nucleotide sequence divergence among genotypes, all currently recognized $\mathrm{HCV}$ genotypes are hepatotropic and pathogenic (Li and Lo, 2015). Infection with HCV leads to an asymptomatic acute stage. However, approximately $75 \%$ of acutely infected patients face a substantial risk of developing chronic $\mathrm{HCV}$ infection. During the 2 decades after infection, $27 \%$ develop liver cirrhosis, and $25 \%$ develop hepatocellular carcinoma (HCC). Worldwide, an estimated 71 million people were living with chronic $\mathrm{HCV}$ infection (1\% of the global population). Whilst, in the European Union/European Economic Area, it was estimated that more than 14 million people were living 
with chronic $\mathrm{HCV}$ infection, suggesting a relatively higher prevalence of $1.5 \%$ in this region (Han et al., 2019). Studies from regional countries showed that $\mathrm{HCV}$ prevalence was $1.1 \%$ in Yemen, less than $1 \%$ in Iran, $1.8 \%$ among young generation in Saudi Arabia, 4.0\% among blood donors in Pakistan and $0.2 \%$ in Iraq (Hussein et al., 2017). In patients undergoing maintenance $\mathrm{HD}$, the prevalence of $\mathrm{HCV}$ infection substantially increases and this disease has been shown to be associated with severe complications from chronic hepatitis to fatal cirrhosis and HCC (Khedmat et al., 2014). The natural history of $\mathrm{HCV}$ infection in dialysis patients remains incompletely understood; controversy continues even in patients with intact kidney function. Defining the natural history of $\mathrm{HCV}$ remains difficult for several reasons: the disease has a very long duration, it is mostly asymptomatic and determining its onset may be difficult (Fabrizi, 2013).

Hepatitis $\mathrm{C}$ virus is the most common cause of post-transfusion hepatitis (PTH) and end-stage liver disease in many countries. Regular blood transfusion in patients with hereditary hemolytic anemia, particularly thalassemia, has improved their overall survival, but carries a definite risk of acquisition of blood-borne virus infections, especially viral hepatitis (Boroujerdnia et al., 2009). Overall, the transmission of $\mathrm{HCV}$ involves direct exposure to contaminated blood and is associated with intravenous drug use, iatrogenic exposures, tattooing, body piercing, and less frequently through vertical transmission and high risk sexual behavior (Najim and Hassan, 2018). Blood transfusions contribute to the expanding transmission pool of viral infections, wherein even an asymptomatic person can transmit the infection. Screening and assessment of donors not only lessens the risk of transmission through infected blood products, but also gives an idea about the prevalence rates of the infections in the community. Evaluation and monitoring the prevalence and trend of $\mathrm{HCV}$ in blood donors is important for assessing quality and effectiveness of donor screening, public education, blood screening tests, and potential risk of transfusion-transmitted $\mathrm{HCV}$ infection (Khodabandehloo et al., 2013). Regulation of screening tests together with the development and introduction of nucleic acid technique tests for HCV has improved blood safety. Despite advances in technology, transfusiontransmitted $\mathrm{HCV}$ infection still exists (Alhilfi et al., 2015). Health care workers wherever they work are at high risk of infectious blood-borne pathogens including $\mathrm{HCV}$. The triggers related to their infection are being in contact with contaminated sharp instruments, injection malpractices, incorrect handling of biological materials, and insufficient education. The number of infected HCWs is often affected by the overall number of $\mathrm{HCV}$ infected population. This rate is often high in HCWs living in less developed countries (Abdelrheem et $a l ., 2020)$. There is no vaccine exists to prevent $\mathrm{HCV}$ infection and treatment for $\mathrm{HCV}$ infection is costly. Thus, the prevention of primary $\mathrm{HCV}$ infection is very important. Any strategy to prevent $\mathrm{HCV}$ infection must be based on accurate data, including information about its prevalence. A few amounts of studies have been done on the prevalence of $\mathrm{HCV}$ infections in past years among Iraqi 
people in some Provinces. However, they are little and incomplete.

The diagnosis of $\mathrm{HCV}$ infection is based on the detection of anti-HCV Abs by enzyme linked immunosorbent assay (ELISA) and it is confirmation by a positive result obtained by an immunoblot assay or by the presence of $\mathrm{HCV}$ RNA. An improvised thirdgeneration anti-HCV-ELISA with high sensitivity is widely used for patients screening. Most of the available thirdgeneration ELISA tests for anti-HCVAbs detection are based on either synthetic peptide antigens (Ags) alone or recombinant protein Ags or a combination of synthetic and recombinant protein Ags of HCV (Kesli, 2011).

\section{STUDY AIMS}

The current study aimed to document the prevalence of $\mathrm{HCV}$ infection among HD patients, thalassemia patients, blood donors and medical staff Iraqi people. Such prevalence presumably might provide a help for prevention strategies of this infection and guide further researches.

\section{MATERIALS and METHODS}

Subjects: A total of 1650 individuals (1180 males and 470 females with an age range 1-85 year) attending the Public Health Laboratory, Hereditary Blood Diseases Center, Central Blood Bank and Renal Dialysis Unit/Al-Hussein Teaching Hospital at Thi-Qar province (Iraq) were enrolled in this study and they are classified into four groups; earliest one included 120 patients with renal failure, the second group included 220 patients suffering from thalassemia, the third group included 1259 blood donors subjects, whereas the last one included
51 subjects from the medical staff. A verbal consent was obtained from each subjects participating in this study to fulfill the international research ethical criteria. This study was carried out from August 2020 to October 2020.

Data collection: Data of age, gender, residency and the result of laboratory test of anti-HCV-IgG-Abs were collected from records of the subjects at the mentioned above medical centers except the medical staff group which is underwent the following:

\section{A. Samples collection and serum} separation: From each subject; 3-4 $\mathrm{ml}$ of peripheral blood was collected by vein puncture. Blood samples were allowed to complete clotting processes at room temperature and then centrifuged at $1500 \mathrm{rpm}$ for 10 minutes to get the sera that have been stored at $20 \mathrm{C}^{\circ}$ until their needed for serological investigation.

B. Serological test: Serological test had been executed in Public Health Laboratory/Health Office of Thi-Qar. Anti-HCV-Abs (IgG) was detected by third generation ELISA kit from MyBioSource (United States of Americans (USA)). This assay employs the indirect qualitative enzyme immunoassay technique. The microtiter plate provided in this kit has been pre-coated with Ags (three recombinant proteins of the nonstructural (NS) region (NS3 and NS4) and a peptide of the structural region). Samples are pipetted into the wells with anti-human immunoglobulin conjugated horseradish peroxidase. Any Abs present in the samples that are specific for the pre-coated Ag will 
bind to it. Following a wash to remove any unbound reagent, a substrate solution is added to the wells and color develops in proportion to the mount of human anti-HCV-Abs bound in the initial step. The color development is stopped and the intensity of color is measured at $450 \mathrm{~nm}$.

Statistical analysis: Statistical package for social sciences version 24 was used. Descriptive statistics included; the use of frequencies and relative frequencies. ChiSquare statistical test were used to test associations between the variables. The results being considered as statistically significant when the P-value was $<0.05$.

\section{RESULTS}

Figure 1 showed the results of antiHCV-(IgG)-Abs in total sum of the study groups. The findings revealed that out of 1650 subjects, only 53 (3.2\%) were infected with $\mathrm{HCV}$. In Figure 2, the results revealed the prevalence of $\mathrm{HCV}$ according to study groups. The highest prevalence was recorded among thalassemia patients $34 / 220 \quad(15.4 \%)$ followed by HD patients 8/120 (6.6\%) and then medical staff group $3 / 51$ (5.8\%), whereas the lowest prevalence was reported among blood donors group $8 / 1259(0.63 \%)$.

The findings of Table (1) were reported that infection rate of the $\mathrm{HCV}$ was higher among males 33/53 (62.3\%) compared to females $20 / 53(37.7 \%)$ with a significant differences $\quad(p<0.05)$ between them.

The results in Table (2) showed a significant different $(p<0.05)$ in $\mathrm{HCV}$ infection rate between age groups of the study subjects. The higher infection percentages were $54.7 \%$ and $28.3 \%$ had been reported in age groups of 1-20 year and 21-40 year, respectively, followed by age group of 41-60 year that had infection percentage $13.2 \%$, while the lower infection rate was recorded at the age group of more than 60 year, which was $3.8 \%$.

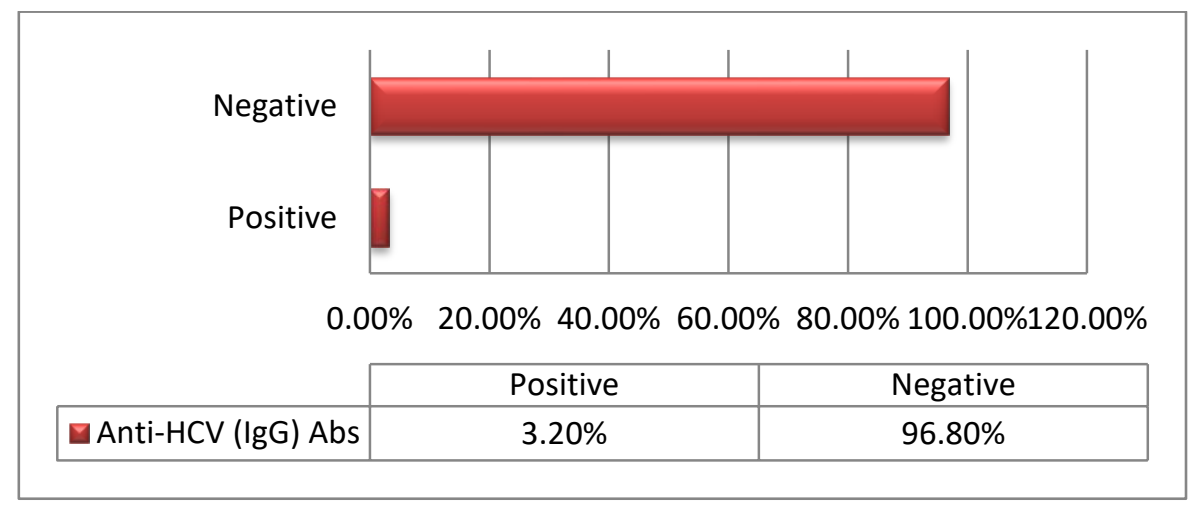

Figure (1): Total prevalence of hepatitis C virus (HCV: Hepatitis $\mathrm{C}$ virus, IgG: Immunoglobulin $\mathrm{G}$ and Abs: Antibodies). 


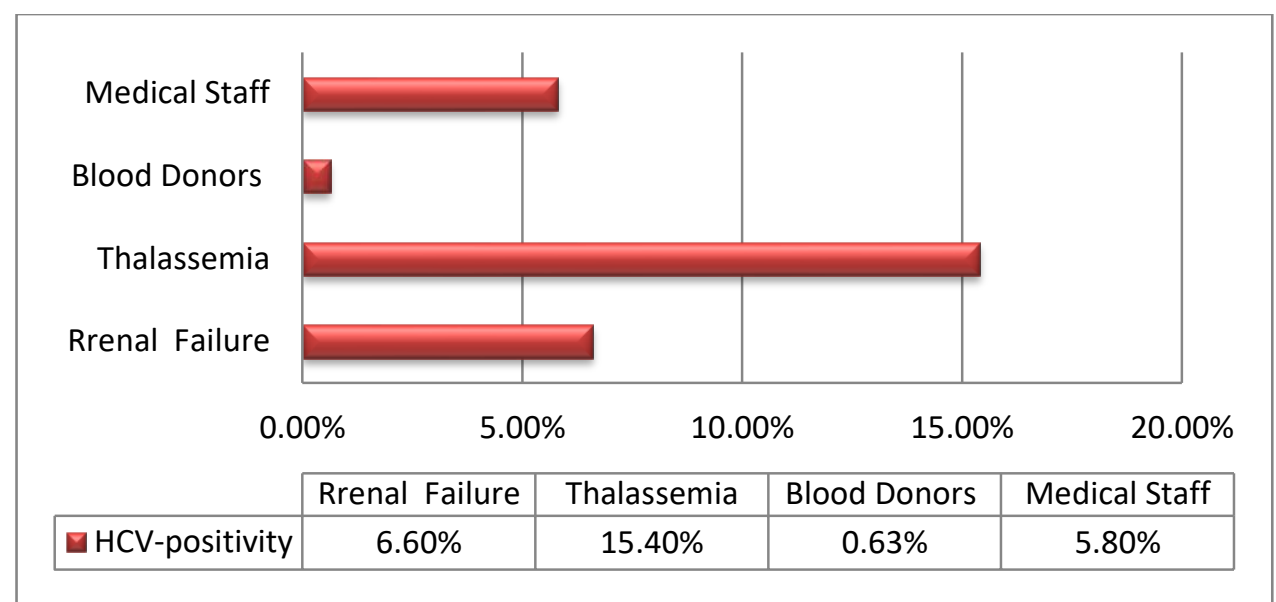

Figure (2): The prevalence of hepatitis $\mathrm{C}$ virus according to the study groups (HCV: Hepatitis $\mathrm{C}$ virus).

Table (1): Prevalence of hepatitis $\mathrm{C}$ virus according to gender of the subjects

\begin{tabular}{|c|c|c|c|}
\hline \multirow{2}{*}{$\begin{array}{c}\text { Study Groups/HCV- } \\
\text { positivity }\end{array}$} & \multicolumn{3}{|c|}{ Anti-Hepatitis C virus Positivity } \\
\cline { 2 - 4 } & Male & Female & Total \\
\cline { 2 - 4 } & FR (\%) & FR (\%) & FR (\%) \\
\hline Renal Dialysis (n=8) & $5(62.5)$ & $3(37.5)$ & $8(100)$ \\
\hline Thalassemia (n=34) & $20(58.8)$ & $14(41.2)$ & $34(100)$ \\
\hline Blood Donors (n=8) & $6(75)$ & $2(25)$ & $8(100)$ \\
\hline Medical Staff $(\mathbf{n}=\mathbf{3})$ & $2(66.7)$ & $1(33.3)$ & $3(100)$ \\
\hline Total $(\mathbf{n}=\mathbf{5 3 )}$ & $\mathbf{3 3 ( 6 2 . 3 )}$ & $\mathbf{2 0}(\mathbf{3 7 . 7})$ & $53(100)$ \\
\hline Statistic & \multicolumn{3}{|c}{ P. <0.05 (S) } \\
\hline
\end{tabular}

HCV: Hepatitis C virus, FR: Frequency, S: Significant and n: Number.

Table (2): Prevalence of hepatitis $C$ virus according to age of the subjects

\begin{tabular}{|c|c|c|c|c|c|}
\hline \multirow{3}{*}{$\begin{array}{c}\text { Age/Study } \\
\text { groups }\end{array}$} & \multicolumn{5}{|c|}{ Anti-Hepatitis C virus positive subjects } \\
\hline & $\begin{array}{c}\text { Renal Dialysis } \\
(n=8)\end{array}$ & $\begin{array}{c}\text { Thalassemia } \\
(n=34)\end{array}$ & $\begin{array}{c}\text { Blood } \\
\text { Donors }(n=8)\end{array}$ & $\begin{array}{c}\text { Medical } \\
\text { Staff }(n=3)\end{array}$ & $\begin{array}{c}\text { Total } \\
(n=53)\end{array}$ \\
\hline & FR (\%) & FR (\%) & FR $(\%)$ & FR (\%) & FR $(\%)$ \\
\hline $1-20 \mathrm{Y}$ & $0(0)$ & $29(85.3)$ & $0(0)$ & $0(0)$ & $29(54.7)$ \\
\hline $21-40 \mathrm{Y}$ & $4(50)$ & $5(14.7)$ & $4(50)$ & $2(66.7)$ & $15(28.3)$ \\
\hline $41-60 \mathrm{Y}$ & $3(37.5)$ & $0(0)$ & $3(37.5)$ & $1(33.3)$ & $7(13.2)$ \\
\hline$>60 Y$ & $1(12.5)$ & $0(0)$ & $1(12.5)$ & $0(0)$ & $2(3.8)$ \\
\hline Total & $8(100)$ & $34(100)$ & $8(100)$ & $3(100)$ & $53(100)$ \\
\hline Statistic & \multicolumn{5}{|c|}{ P. $<0.05(\mathrm{~S})$} \\
\hline
\end{tabular}

Y: year, FR: Frequency, S: Significant and n: Number. 


\section{DISCUSSION}

Hepatitis $\mathrm{C}$ virus infections are among the most prevalent infectious diseases in humans worldwide and it is associated with a broad range of clinical presentations ranging from acute or fulminant hepatitis to chronic infection that may be clinically asymptomatic or may progress to chronic hepatitis and liver cirrhosis. The prevalence of $\mathrm{HCV}$ infection varies from one country to another depending upon a complex mixture of behavioral, environmental and host factors (Tarky et al., 2013). The prevalence rate of $\mathrm{HCV}$ infection is decreasing in the developed countries; whereas, in developing countries such as Iraq, researchers still struggle to control the infection (Messina et al., 2015). However, the prevalence of $\mathrm{HCV}$ infection in the general population in Iraq is not available due to the unstable political and social situation for the past decades. To the best of our knowledge, the only published data on the prevalence of viral hepatitis in Iraq are from blood donor studies.

Different studies from neighbouring countries showed a variation in the prevalence rates of $\mathrm{HCV}$ ranging from $0.4 \%$ to $19.2 \%$ (Vriend et al., 2013). In this study the total prevalence of HCV infection was $3.2 \%$ (Figure 1). Consistent with our findings, another previous study at Duhok City (Iraq) found that the prevalence of $\mathrm{HCV}$ was 2.8\% (Hussein et al., 2017). On other hand, the results of current study less than those in previous study conducted in Iraq by Hamied et al., (2010) that reported the HCV prevalence in Baghdad province $(8.3 \%)$ and more than the findings obtained Tarky et al., (2013) in all over Iraqi governorates $(0.4 \%)$ and
Abdul-Kareem et al., (2001) in Al-Najaf province $(0.34 \%)$. In comparison with results of the previous studies in other countries, the findings of the current study are in agreement with those in Turkey (2.4\%)\% (Erden et al., 2003), Thailand (2.8\%) and Vietnam (2-2.9\%), and less than those in Taiwan (4.4\%), Pakistan (4.7\%) and Egypt (14.9\%), and more than those in Iran $(0.5 \%)$, USA $(0.01 \%)$, Australia (1.3\%), China (1$1.9 \%)$, Saudi Arabia (1-1.9\%) and Syria (1-1.9\%) (Yen et al., 2003, Mostafa et al., 2010, Merat et al., 2010 and Sievert et al., 2011). These differences in the prevalence rate might be explained in part by the difference in study population, samples collection method and the techniques used in the diagnosis. Further population based studies are needed to explore this.

Patients with thalassemia and hemoglobinopathies need frequent blood transfusions which are important for improvement of their survival and reduce dangerous complications that produce from severe anemia. On other hand, this frequent blood transfusions will increase the probability of infection with different microbes especially; $\mathrm{HCV}$, hepatitis B virus and human immunodeficiency virus (Rund and Rachmilewitz, 2005). Consistent with these findings, the prevalence ratio of $\mathrm{HCV}$ in our study was $15.4 \%$ (Figure 2) from 220 patients suffer from thalassemia. Previous studies in Duhok city (Al-Khaffaj and AlGhazal, 2019) and Mosul City-Iraq (Khalid and Abdullah, 2012) revealed that the prevalence of $\mathrm{HCV}$ among thalassemia patients were $11.05 \%$ and $17 \%$, respectively, which in line with current data. The results of the current study was lower than other previous 
studies in other Iraqi cities including Diyala (26.4\%) (Raham et al., 2011) and Karbala (37\%) (Al-Greti, 2013), and higher than Babylon city (7.5\%) (Tarish and Shakeer, 2014). These variation in the prevalence of HCV may be belong to variation in hygienic surveillance especially tests of blood. In addition, it reflects the variation of health awareness of the citizens in these cities. Hepatitis $\mathrm{C}$ virus characterized with low viral load, long incubation period which may be extended to six months and asymptomatic in acute and chronic periods, all these reasons will delay the seroconversion and finally, delay diagnosis of $\mathrm{HCV}$ in blood donors leading to increase the probability of HCV-infection among patients with thalassemia and hemoglobinopathies through hemolysis and this interprets the increasing of $\mathrm{HCV}$-infection in thalassemia patients in our study. To reduce the $\mathrm{HCV}$-infection, many countries insert the molecular biology technology within the routine protocol tests which recognize very low concentration of viral RNA (Whittaker $e t$ al., 2008).

In $\mathrm{HD}$ centers, $\mathrm{HCV}$ infection remains a major concern. Blood transfusion as well as nosocomial infection continues to play important roles in the transmission of HCV (Su et al., 2013). An overall prevalence of $6.6 \%$ of $\mathrm{HCV}$ infection was reported among HD patients in the Thi-Qar province according to the present study (Figure 2). This finding is closer to that reported in Baghdad province $(7.1 \%)$ (Khattab, 2008) and AlAnbar province (11.7\%) (AlMashshhhadani, 2006). This prevalence is low when compared to reports from Sulaimani (Iraq) (26.7\%) (Ramzi et al.,
2010) and in other developing countries; (26\%) in Hungary (MendezSanchez et al., 2004), (24\%) in Iran (Alavian et al., 2003), (30\%) in India and (26\%) in Oman (Alavian et al., 2003), but, it high when compared to reports from western countries; United Kingdom (0.4\%) (Jadoul et al., 2004) and Mexico (1.2\%) (Mendez-Sanchez et al., 2004).

As previously illustrated above $\mathrm{HCV}$ is a blood borne virus transmitted by the parenteral route. Infection frequently results in a chronic asymptomatic carrier state for many years before the development of symptomatic liver disease. Hepatitis C virus infected HCWs may therefore be unaware of their condition and their potential to infect patients. Healthcare workers, who perform exposure prone procedures, where injury to the workers may result in exposure of the patient's open tissues to the blood of the workers, are theoretically at increased risk of infection with blood borne viruses (Thorburn et al., 2001). In the current study we found that the prevalence of $\mathrm{HCV}$ among HCWs was $5.8 \%$ (Figure 2). It is closer to the results of ALHaj et al., (2019) and Ansari and Dixit (2017) studies that conducted in Yemen $(4.17 \%)$ and India (4\%) among HCWs, respectively. However, it was more than the prevalence of $\mathrm{HCV}$ among HCWs in Dhaka-Bangladesh, Poland and India (1\% and $1.9 \%$ and $3 \%$, respectively) (Shah et al., 2017). This difference is because the HCWs adopt different preventive degree measures in different health-care centers. An overall, the present study may be helpful for understanding the prevalence of $\mathrm{HCV}$ 
among HCWs in Thi-Qar province (Iraq).

For the prevalence of $\mathrm{HCV}$ among blood donors, our study showed that the prevalence of HCV-Abs was $0.63 \%$. In agreement with these findings, previous studies in Baghdad (Ataallah et al., 2011) and Babylon (Al-Juboury et al., 2010) governorates showed a closer prevalence rate of $\mathrm{HCV}$ infection $(0.7 \%$ and $0.5 \%$, respectively). On comparison with other countries, the prevalence of HCV among Kuwaiti national and non-Kuwaiti Arab first-time donors were found to be 0.8 and $5.4 \%$, respectively (Ameen et al., 2005). In Jordan, a hospital-based study showed that the infection with HCV among blood donors was $0.9 \%$ (Al-Gani, 2011). Overall, the variations in the prevalence of $\mathrm{HCV}$-infection may belong to different reasons such as sample size, type of technique used (ELISA, Minividas, Immunofluorescences or Chemiluminescence), variations in kit types and their trade mark, time of incubation during the test and the differences in blood test procedures between countries, cities and societies. In addition to that, the variations in customs and social customs in each society such as tattoo, body piercing and take drugs by injection. The level of hygienic surveillance as well as hygienic awareness of people may interpret all these variations in results. The results of the present study exhibited significantly higher frequency percent of $\mathrm{HCV}$ positivity among males compared to females (Table 2). The current study findings are consistent with previous findings that reported by others authors in Iraq (Abdul-Sada, 2011), Iran (Shakeri et al., 2013), Pakistan in blood donors, India in outpatients clinic visitors (Sood and Malvankar, 2010) and USA blood donors (Sheikh et al., 2013) as the prevalence was higher in males than females. In Egypt, higher $\mathrm{HCV}$ prevalence was detected in males compared to females among village residents (Sharaf-Eldin et al., 2007) and blood donors (Rushdy et al., 2009). In Pakistan, although the probability trends were slightly higher in males of all age groups than in females, the differences not statistically significant (Anwar et al., 2013). In a nationwide survey in Poland did not indicate a significant effect of gender on $\mathrm{HCV}$ prevalence (Hartleb et al., 2012). Considering the age groups distribution, the prevalence of $\mathrm{HCV}$ infection was significantly highest among persons with age group (1-20 year) and followed by age group (21-40 year) (Table 2), and these results were in agreement with Amin et al., (2004), that reported the 20-24 year old age group had the highest prevalence with strong majority of the infected population below the age of 50. In Western Pacific the pattern of seroprevalence across age in Australasia exhibits a rapid increase in prevalence peaking at 20-24 years age. In addition, in Central Europe an early peak in ages of 1-4 year is seen in Central Europe (Mohd et al., 2013). The prevalence of $\mathrm{HCV}$ infection showed a decrease with age after 60 years old, which may due to the decline in physical mobility and economic strength that leads to decrease the number of elderly examination.

\section{Conclusions}

The prevalence rate of $\mathrm{HCV}$ infection among Iraqi people is $3.2 \%$, which is similar to those in most of Asian and non-Asian studied populations and the infection rate was higher in males and 
inversely correlated with age of the patients. Blood transfusion, renal dialysis and $\mathrm{HCW}$ sere major sources of $\mathrm{HCV}$ infection. Thalassemic and HD patients are at risk of acquiring $\mathrm{HCV}$ infection. Therefore, blood donor screening protocol and effective screening techniques are likely to be needed to prevent speared of HCV infection among them. The risk of HCV infection is more among HCWs, hence HCWs should take proper precaution while handling blood. Aseptic procedures should be carried out to prevent needle stick injury.

In Iraq, information about the prevalence of $\mathrm{HCV}$ infections has generally been limited to laboratory data and personal interest of research projects in certain education institutes. Thus, we recommend continuing surveillance of blood donors, HCWs and patients, in addition to $\mathrm{HCV}$ markers screening by special type of molecular technique (polymerase chain reaction) for the diagnosis of $\mathrm{HCV}$ during the window period in order to decrease the prevalence of $\mathrm{HCV}$-infection.

\section{Acknowledgements}

We would like to thank the staff of all medical centers mentioned above for their infinite help and efforts during the data and samples collection. We also express our full heart gratitude to all the patients, volunteers and their families for their great assistance and cooperation. Special thanks to the staff of Training and Human Development Center/Health Office of Thi-Qar for their infinite help and efforts by facilitating the task of completing this research in coordination with the concerned medical centers.

\section{References}

Abdelrheem S. S.; Saleh Y. Y.; Abdelatif H. A. and Elbadry M. M. Hepatitis C Infection among Health Care Workers in Aswan: Seroprevalence and Risk Factors. Journal of High Institute of Public Health, 2020; 50(1): 58-64.

Abdul-Kareem A.; Salman A.; Addose H.; Salih A. M. and AlKhaldi A. Seroprevalence of $\mathrm{HBcAg}$ and anti-HCV positive blood donors in Najaf Governorate. Iraqi J. Comm. Med., 2001; 14: 7-11.

Abdul-Sada K. M. Estimation of $\mathrm{HCV}$ genome genotyping and the role of Mosquitoes in its transmission. Ph. D. Thesis, College of Medicine, University of Kufa, Iraq, 2011.

Alavian S. M.; Einollahi B.; Hajarizadeh B.; Bakhtiari S.; Nafar M. and Ahrabi M. Prevalence of hepatitis $\mathrm{C}$ virus infection and related risk factors among patients on hemodialysis. Nephrology, 2003; 8: 256-260.

Al-Gani E. A. Prevalence of HBV, HCV and HIV-1, 2 infections among blood donors in Prince Rashed Ben Al-Hassan Hospital in North Region of Jordan. Int. J. Bol. Med. Res., 2011; 2: 912-916.

Al-Greti S. H. H. Prevalence of hepatitis $\mathrm{C}$ virus in Beta-Thalassemia major patients at Karbala governorate. J. Uni. Babylon, 2013; 21: 2801-2805.

ALHaj N. A.; AlMaktari H. M.; AlShamahy $\mathrm{H}$. and AlMouid K. A. Hepatitis c virus among health care workers and the risk factors contributing for its infection. 
International Journal of Scientific Research, 2019; 8(4): 34-36.

$>$ Alhilfi H. S. Q.; Alhashimi R. A. H. and Alsaad R. K. A. Seroprevalence of Hepatitis B and Hepatitis C Virus Among Blood Donors in Missan Governorate-Iraq. International Journal of Innovation and Applied Studies, 2015; 11(3): 816-820.

$>$ Al-Juboury A. W. F.; AL-ASSADI M. K. and Ali A. M. Seroprevalence of hepatitis B and C among blood donors in Babylon Governorate-Iraq. Med. J. Babylon, 2010; 7 (1-2):121129.

$>$ Al-Khaffajy A. A. and Al-Ghazal A. T. Y. Prevalence of hepatitis $C$ virus in thalassemia and hemoglobinopathies in Duhok City/Iraq. Research Journal of Medical Sciences, 2019; 13(1): 1115.

> Al-Mashshhhadani J. I. Hepatitis C virus infection among haemodialysis patients in $\mathrm{Al}-$ Anbar governorate. Iraqi J. Comm. Med., 2006; 20(1): 20-24.

$>$ Ameen R.; Sanad N.; Al-Shemmari S.; Siddique I.; Chowdhury R. I.; AlHamdan S. and Al-Bashiret A. Prevalence of viral markers among first-time Arab blood donors in Kuwait. Transfusion, 2005; 45(12): 1973-1980.

> Amin J.; Gidding H.; Gilbert G.; Backhouse J.; Kaldor J.; Dore G. and Burgess M. Hepatitis C prevalence a nationwide serosurvey. Commun. Dis. Intell., 2004; 28(4): 517-521.

$>$ Ansari A. M. and Dixit S. Hepatitis C virus infection in health care workers: A clinical study. International Journal of Medical and Health Research, 2017; 3(2): 41-43.
Anwar M. I.; Rahman M.; Hassan M. $\mathrm{U}$. and Iqbal M. Prevalence of Hepatitis C virus infections among general public of Lahour Pakistan. Virol. J., 2013; 10: 351.

Ataallah T. M.; Hanan K. A.; Maysoun K. S. and Sadoonet A. A. Prevalence of hepatitis B and C among blood donors attending the National Blood Transfusion Center in Baghdad, Iraq from 2006-2009. Saudi Med. J., 2011; 32: 1046-1050.

Boroujerdnia M. G.; Zadegan M. A. A.; Zandian K. M. and Rodan M. H. Prevalence of Hepatitis-C virus (HCV) among Thalassemia Patients in Khuzestan Province, Southwest Iran. Pak. J. Med. Sci., 2009; 25(1): 113-117.

Erden S.; Buyukozturk S.; Calangu S.; Yilmaz G.; Palanduz S. and Badur S. A study of serological markers of hepatitis $\mathrm{B}$ and $\mathrm{C}$ viruses in Istanbul, Turkey. Med. Princ. Pract., 2003; 12: 184-188.

Fabrizi F. Hepatitis C Virus Infection and Dialysis: 2012 Update. International Scholarly Research Notices, 2013; 2013: 1-14.

Hamied L.; Abdulla R. M. and Abdulla A. M. Seroprevalence of hepatitis $\mathrm{B}$ and $\mathrm{C}$ virus infection in Iraq. The N. Iraq J. Med., 2010; 6: 69-73.

Han R.; Zhou J.; François C. and Toumi M. Prevalence of hepatitis C infection among the general population and high-risk groups in the EU/EEA: a systematic review update. BMC Infectious Diseases, 2019; 19: 655.

Hartleb M.; Gutkowski K.; Zejda J. E.; Chudek J. and Więcek A. Serological prevalence of Hepatitis B 
virus and $\mathrm{C}$ virus infection in the elderly populating: Polish nationwide survey - PolSenior. European Journal of Gastroenterology and Hepatology, 2012; 24(11): 1288-1295.

$>$ Hussein N. R.; Balatay A. A.; Sezgin A. T. and Jawad R. S. The distribution of $\mathrm{HCV}$ in subjects attending hospitals in Duhok City, Iraq. Asian Pacific Journal of Tropical Biomedicine, 2017; 7(3): 262-264.

$>$ Jadoul M.; Poignet J. L.; Geddes C.; Locatelli F.; Medin C.; Krajewska M.; Barril G.; Scheuermann E.; Sonkodi S.; Goubau P. and HCV Collaborative Groupe. The changing epidemiology of hepatitis $\mathrm{C}$ virus (HCV) infection in hemodialysis: European multicenter study. Nephrol. Dial. Transplant., 2004; 19(4): 904-909.

$>$ Kesli R. Evaluation of assay methods and false positive results in the laboratory diagnosis of hepatitis $\mathrm{C}$ virus infection. Archives of Clinical Microbiology, 2011; 2(1): 1-4.

$>$ Khalid M. D. and Abdullah B. A. Prevalence of anti-HCV antibodies among Thalassemia patients in Mosul City, Iraq. J. Life Sci., 2012; 6: 489491.

$>$ Khattab O.S. Prevalence and risk factors for hepatitis $\mathrm{C}$ virus infection in hemodialysis patients in an Iraqi renal transplant center. Saudi J. Kidney Dis. Transpl., 2008; 19( 1): 110-115.

$>$ Khedmat H.; Amini M.; Chehreh M. E. G. and Agah S. Hepatitis C Virus Infection in Dialysis Patients. Saudi Journal of Kidney Diseases and Transplantation, 2014; 25(1): 1-8.
Khodabandehloo M.; Roshani D. and Sayehmiri K. Prevalence and trend of hepatitis $\mathrm{C}$ virus infection among blood donors in Iran: A systematic review and meta-analysis. J. Res. Med. Sci., 2013; 18(8): 674-682.

Li H. C. and Lo S. Y. Hepatitis C virus: Virology, diagnosis and treatment. World J. Hepatol., 2015; 7(10): 1377-1389.

Mendez-Sanchez N.; Motola-Kuba D.; Chavez-Tapia N. C.; Bahena J.; Correa-Rotter R. and Uribe $\mathrm{M}$. Prevalence of hepatitis $\mathrm{C}$ virus infection among hemodialysis patients at a tertiary-care hospital in Mexico city. Mexico. J. of Clin. Microbiol., 2004; 42( 9): 4321-4322. Merat S.; Rezvan H.; Nouraie M.; Jafari E.; Abolghasemi H.; Radmard A. R.; Zaer-rezaii H.; Amini-Kafiaba S.; Maghsudlu M.; Pourshams A.; Malekzadeh R. and Esmaili S. Seroprevalence of hepatitis C virus: the first population-based study from Iran. International Journal of Infectious Diseases, 2010; 14S: e113-e116.

Messina J. P.; Humphreys I.; Flaxman A.; Brown A.; Cooke G. S.; Pybus O. G. and Barneset E. Global distribution and prevalence of hepatitis $\mathrm{C}$ virus genotypes. Hepatology, 2015; 61 (1): 77-87.

Mohd H. K.; Groeger J.; Flaxman A. D. and Wiersm S. T. Global epidemiology of Hepatitis C virus infection: new estimates age-specific antibody to HCV seroprevalence. Hepatology, 2013; 57(4): 1333-1342. Mostafa A.; Taylor S. M.; El-Daly M.; El Hoseiny M.; Bakr I.; Arafa N.; Thiers V.; Rimlinger F.; AbdelHamid M.; Fontanet A. and 
Mohamed M. K. Is the hepatitis C virus epidemic over in Egypt? Incidence and risk factors of new hepatitis $\mathrm{C}$ virus infections. Liver international, 2010; 30(4): 560-566.

$>$ Najim O. A. and Hassan M. K. Prevalence of hepatitis $\mathrm{C}$ virus seropositivity among multitransfused patients with hereditary anemias in Basra, Iraq. Iraqi Journal of Hematology, 2018; 7(1): 39-44.

$>$ Raham T. F.; Wahed S. S. A. and Alhaddad H. N. Prevalence of hepatitis $\mathrm{C}$ among patients with $\beta$ Thalassemia in Diyala-Iraq. AlTaqani J., 2011; 24: 113-120.

$>$ Ramzi Z. S.; Abdulla A. A.; ALHadithi T. and Al-Tawil N. Prevalence and Risk Factors for Hepatitis C Virus Infection in Hemodialysis Pateints in Sulaimani. Zanco J. Med. Sci., 2010; 14(Special issue 1): 44-50.

$>$ Rund D. and Rachmilewitz E. $\beta$ Thalassemia. New Engl. J. Med., 2005; 353: 1135-1146.

$>$ Rushdy O.; Moftah F. and Zakarya S. Transmitted transfused viral infection among blood donors during years 2006 and 2007 in Suez canal area Egypt. Vax Sang, 2009; 96: 86-87.

$>$ Shah D. K.; Jain S. S.; Khot A. A.; Gharat A. R.; Rajadhyaksha G. C. and Rathi P. M. Low prevalence of hepatitis $\mathrm{B}$ and $\mathrm{C}$ infections among the healthcare workers despite low vaccination coverage for hepatitis $B$ in Mumbai. Indian J. Med. Sci., 2017; 69: 8-12.

> Shakeri M. T.; Nomani H.; Mobarhan M. G.; Sima H. R.; Gerayli S.; Shahbazi S.; Rostami S. and Meshkat $Z$. The prevalence of hepatitis $C$ virus in Mashhad, Iran: a population-based study. Hepat. Mon., 2013; 3(3): e7723.

Sharaf-Eldin S.; Salama K.; Eldemedresh S.; Hassan H. M. S. and Semsem M. Hepatitis B and C viruses in Egyptian children with malignancy. J. Med. Sci., 2007; 7(6): 1003-1008.

Sheikh M. Y.; Atla P. R.; Ameer A.; Sadiq H. and Sadler P. C. Seroprevalence Hepatitis B and C infections among healthy volunteer blood donors in the central California Valley. Gut and Liver, 2013; 7(1): 66-73.

Sievert W.; Altraif I.; Razavi H. A.; Abdo A.; Ahmed E. A.; AlOmair A.; Amarapurkar D.; Chen C. H.; Dou X.; El Khayat H.; elShazly M.; Esmat G.; Guan R.; Han K. H.; Koike K.; Largen A.; McCaughan G.; Mogawer S.; Monis A.; Nawaz A.; Piratvisuth T.; Sanai F. M.; Sharara A. I.; Sibbel S.; Sood A.; Suh D. J.; Wallace C.; Young K. and Negro F. A systematic review of hepatitis $\mathrm{C}$ virus epidemiology in Asia, Australia and Egypt. Liver International, 2011; 31(2): 61-80.

Sood S. and Malvankar S. Seroprevalence of Hepatitis B surface antigen, antibodies to the Hepatitis $\mathrm{C}$ virus, and human immunodeficiency virus in a hospital-based population in Jaipur, Rajasthan. Indian J. Community Med., 2010; 35(1): 165169.

Su Y.; Norris J. L.; Zang C.; Peng Z. and Wang N. Incidence of hepatitis $\mathrm{C}$ virus infection in patients on hemodialysis: a systematic review and meta-analysis. Hemodial. Int., 2013; 17: 532-541. 
Tarish A. H. and Shakeer W. H. Hepatitis $\mathrm{C}$ infection among children with Beta-Thalassemia major in Babylon center of hereditary blood disorders. Kerbala J. Med., 2014; 7: 1945-1951.

Tarky A. M.; Akram W.; Al-Naaimi A. S. and Ome A. R. Epidemiology of viral hepatitis $\mathrm{B}$ and $\mathrm{C}$ in Iraq: a national survey 2005-2006. Zanco J. Med. Sci., 2013; 17(1): 370-380.

$>$ Thorburn D.; Dundas D.; McCruden E. A. B.; Cameron S. O.; Goldberg D. J.; Symington I. S.; Kirk A. and Mills P. R. A study of hepatitis C prevalence in healthcare workers in the West of Scotland. Gut, 2001; 48: 116-120.

> Vriend H. J.; Van Veen M. G.; Prins M.; Urbanus A. T.; Boot H. J. and Op De Coul E. L. M. Hepatitis C virus prevalence in The Netherlands: migrants account for most infections. Epidemiol. Infect., 2013; 141 (6): 1310-1317.

> Whittaker S.; Carter N.; Arnold E.; Shehata N. and Webert K. E. Understanding the meaning of permanent deferral for blood donors. Trans., 2008; 48: 64-72.

$>$ Yen T.; Keeffe E. B. and Aijaz Ahmed. The Epidemiology of Hepatitis C Virus Infection. J. Clin. Gastroenterol., 2003; 36(1): 47-53. 